\title{
Perbaikan estetik gigi anterior yang protrusi dengan gigitiruan imidiat yang disertai dengan alveolektomi interseptal
}

\author{
Ike Damayanti Habar \\ Bagian Prostodonsia \\ Fakultas Kedokteran Gigi Universitas Hasanuddin \\ Makassar, Indonesia
}

\begin{abstract}
Generally, the treatment of immediate partial denture has the objective of enhancing the aesthetics of the condition and position of protrusive anterior teeth that would improve the appearance. Case study was carried out on 16-years-old female patient with overjet far from normal that obstruct closing of the lips. The patient's profile looks convex with the labial maxilla protrudes and a clear undercut in anterior region. The diagnosis of patient was dentoalveolar protrusion along with multiple diastema, malocclusion class II division I of skeletal relation that caused by localized aggressive periodontitis. The treatment was construction of immediate partial denture with immediate extraction of maxillary anterior teeth accompanied with interseptal alveolectomy. Control was done 24 hours, three days, and seven days after insertion. Aesthetics, occlusion, articulation, retention dan stabilization looked very good.

Key words: immediate partial denture, interseptal alveolectomy, aesthetics.
\end{abstract}

\begin{abstract}
ABSTRAK
Pada umumnya perawatan dengan menggunakan gigitiruan sebagian imidiat bertujuan untuk memperbaiki estetik dari kondisi dan posisi gigi anterior yang protrusi sehingga akan memperbaiki penampilan wajah penderita. Studi kasus dilakukan terhadap penderita perempuan berumur 16 tahun dengan overjet yang jauh lebih besar dari normal sehingga gigi anterior rahang atas menghalangi penutupan bibir. Profil penderita tampak convex dengan bagian labial maxilla yang menonjol dan undercut yang nyata pada regio anterior. Diagnosis penderita adalah dentoalveolar protrusion rahang atas yang disertai multiple diastema dengan maloklusi kelas II divisi 1 hubungan skeletal yang disebabkan oleh localized aggressive periodontitis. Perawatan yang dilakukan adalah pembuatan gigitiruan sebagian imidiat dengan ekstraksi pada gigi anterior rahang atas yang disertai dengan alveolektomi interseptal. Setelah insersi dilakukan kontrol 24 jam, tiga hari, dan tujuh hari. Estetik, oklusi, artikulasi, retensi dan stabilisasi tampak sangat baik.
\end{abstract}

Kata kunci: gigitiruan sebagian imidiat, alveolektomi interseptal, estetik.

Koresponden: Ike Damayanti Habar, Bagian Prostodonsia, Fakultas Kedokteran Gigi Universitas Hasanuddin. Jl. Kandea no. 5 Makassar. Telepon: 0411-5612937, e-mail: iffah06@yahoo.com

\section{PENDAHULUAN}

Ketidakteraturan letak gigi yang parah atau protrusi yang berat pada gigi anterior dapat memberikan efek psikologis yang tidak menguntungkan terutama bagi pasien wanita muda. Walaupun perawatan ortodontik dapat dilakukan dan harus selalu dipertimbangkan, tetapi dalam beberapa kasus, pencabutan gigi yang 
bermasalah lebih dianjurkan. Hal ini terutama bila proklinasi gigi anterior yang disebabkan oleh kehilangan tulang pendukung. Pada kehilangan tulang akibat penyakit periodontal, sering terlihat migrasi ke arah labial dan terbentuk jarak antar gigi. ${ }^{1}$

Gigitiruan imidiat dapat didefinisikan sebagai gigitiruan yang dibuat atau dikonstruksikan terlebih dahulu sebelum gigi alami dicabut, dan segera diinsersikan setelah pencabutan gigi tersebut. ${ }^{1}$ Gigitiruan imidiat dapat berupa gigitiruan penuh atau gigitiruan sebagian. Penggantian imidiat untuk gigi anterior merupakan jenis yang paling sering dari gigitiruan imidiat. Ada dua macam bentuk gigitiruan imidiat, yaitu gigitiruan imidiat dengan sayap atau labial flanged dan gigitiruan imidiat tanpa sayap atau open face/socketing. ${ }^{2}$

Gigitiruan imidiat dengan sayap lengkap dikhususkan sebagai terapi kepada penderita dengan rahang yang prognathi dengan gigi-gigi yang protrusi, ekstrusi dan mungkin diastema, yang memerlukan rehabilitasi estetik dengan disertai pengurangan tulang. ${ }^{3}$

Indikasi perawatan dengan menggunakan gigitiruan imidiat adalah bila penderita mengalami karies yang parah pada gigi anterior atau perubahan warna yang hebat yang disebabkan oleh faktor ekstrinsik atau intrinsik. Gigi yang mengalami kelainan periodontal yang parah ditandai dengan hilangnya perlekatan periodontal dan kerusakan pada tulang alveolus sehingga menyebabkan kegoyangan yang hebat. Kelainan posisi dan susunan gigi anterior seperti protrusi, retrusi, berdesakan, gigitan terbalik/silang, dapat pula disertai dengan kelainan bentuk rahang. ${ }^{1}$

Kontraindikasi perawatan dengan menggunakan gigitiruan imidiat adalah bila penderita mengalami abses periapikal atau abses periodontal, penyakit diabetes yang tidak terkontrol, penyakit haemofilia, terdapat riwayat penyakit rematik dengan kerusakan jantung, telah menjalani terapi radiasi, terdapat kista atau gigi yang impaksi, riwayat pencabutan gigi yang sukar, kesehatan mulut yang buruk serta tidak kooperatif. ${ }^{1}$

Adapun keuntungan utama dari penggunaan gigitiruan imidiat adalah penderita terhindar dari rasa tidak nyaman dan khawatir bila terlihat tidak bergigi atau ompong karena dapat segera memakai gigitiruan. Perawatan ini memungkinkan penderita untuk tetap melakukan kegiatan sosial ataupun bisnis. ${ }^{4,5}$ Keuntungan lain adalah gigitiruan ini bertindak sebagai bandage, splint untuk mengontrol perdarahan, melindungi luka dari trauma karena makanan atau gigi antagonis, mencegah cairan mulut dan partikel makanan masuk ke dalam soket gigi serta melindungi bekuan darah sehingga mempercepat proses penyembuhan. ${ }^{6}$

Kekurangan dari perawatan ini adalah susunan gigi dan estetik tidak dapat diperiksa sebelum proses akrilik dan insersi gigitiruan sehingga diperlukan perencanaan yang lebih cermat. $^{7,8}$ Biaya perawatan dengan menggunakan gigitiruan imidiat yang lebih mahal daripada pembuatan gigitiruan yang konvensional karena memerlukan reline atau bahkan pembuatan gigitiruan yang baru. Selain itu, diperlukan kerjasama dan waktu perawatan yang lebih lama antara dokter gigi, pasien dan laboratorium dental. $^{7}$

Pada kasus dengan daerah undercut yang sangat berat dan direncanakan pengurangan bagian anterior rahang atas yang menonjol, diperlukan pembedahan untuk pembentukan bagian anterior lingir alveolaris sehingga posisi penyusunan gigi artifisial dapat lebih retrusi dari gigi alami terdahulu. Pengurangan tulang alveolus 
atau alveoplasty dapat dilakukan dengan alveolektomi interseptal. ${ }^{1,3}$

Penting bagi dokter gigi untuk mengetahui cara melakukan perubahan atau pengasahan model kerja, khususnya pada pasien dengan perencanaan perawatan dengan menggunakan gigitiruan sebagian imidiat yang disertai dengan alveolektomi interseptal, sehingga dapat melakukan penyusunan gigi artifisial dengan posisi yang lebih retrusi dari gigi-gigi alami terdahulu. Selanjutnya teknik pembedahan, yaitu tindakan pencabutan gigi-gigi alami yang kemudian diikuti dengan alveolektomi interseptal sebelum penempatan gigitiruan. ${ }^{9} \quad$ Hal ini dilakukan agar tercapai perbaikan estetik pada gigi anterior yang akan memperbaiki penampilan wajah.

Penulisan laporan kasus ini bertujuan untuk memaparkan perbaikan estetik gigi anterior yang protrusif dengan gigitiruan imidiat yang disertai dengan alveolektomi interseptal, pengasahan model kerja di laboratorium dan pelaksanaan tindakan pembedahan pada pasien sebelum penempatan gigitiruan.

\section{KASUS}

Penderita seorang perempuan, berusia 16 tahun, dan tidak memiliki pekerjaan. Pasien datang dengan keluhan gigi depannya yang tonggos sehingga bibirnya sama sekali tidak bisa menutup. Penderita walaupun masih dalam usia sekolah tetapi tidak melanjutkan pendidikannya karena merasa malu dengan keadaan gigi-gigi tersebut saat itu. Penderita belum pernah memakai gigitiruan sebelumnya. Setahun sebelumnya penderita pernah merawat giginya di Bagian Ortodonsia sebuah rumah sakit dengan tujuan untuk merapikan gigi-gigi tersebut tetapi tidak berhasil. Malah gigi depannya terlihat semakin maju dan renggang sehingga bibir atas dan bawahnya tidak dapat dirapatkan lagi. Penderita mengharapkan gigitiruan yang dapat memperbaiki estetik wajahnya Dari pemeriksaan ekstra oral tampak bibir yang tidak dapat menutup tersebut disebabkan oleh gigi anterior rahang atas yang sangat protrusi. Dari pemeriksaan intra oral tampak sisa akar dengan polip gingival pada gigi 36 dan 46. Gigi goyang derajat 2 pada gigi 11 dan 21. Gigi labioversi disertai retraksi gingiva pada gigi 23, 22, 21, 11, 12, dan 13. Multiple diastema pada regio anterior rahang atas. Tampak pula pada hubungan gigi anterior ada overjet 16,5 $\mathrm{mm}$ dan overbite $-3 \mathrm{~mm}$. Pada pemeriksaan radiografi, tampak resorbsi tulang alveolar sampai 1/3 apikal pada gigi 11 dan 21 dan resorbsi tulang alveolar sampai $1 / 2$ apikal pada gigi $22,12,32$, dan 35. Dari analisis sefalometri ditentukan bahwa penderita mengalami maloklusi kelas II divisi I hubungan skeletal. Inklinasi insisivus rahang atas protrusi sedangkan inklinasi insisivus rahang bawah normal. Penderita didiagnosis sebagai protrusi dentoalveolar rahang atas yang disertai multiple diastema yang disebabkan oleh localized aggressive periodontitis (Gambar 1A dan B).

Untuk kasus ini direncanakan perawatan dengan gigitiruan sebagian imidiat dengan ekstraksi imidiat pada gigi 13, 12, 11, 21, 22, dan 23 yang disertai dengan alveolektomi interseptal pada regio 12, 11, 21, dan 22.

\section{Tahap perawatan}

Serangkaian tahap perawatan, dimulai dengan persiapan, yaitu pembuatan foto panoramik, sefalometri, dan model diagnostik. Selanjutnya dilakukan pengasahan untuk lintasan klamer pada gigi 14, 16, 24, dan 26. Persiapan diakhiri dengan mencetak untuk membuat model kerja, dilanjutkan dengan penetapan gigit dan memasang model kerja pada artikulator. 


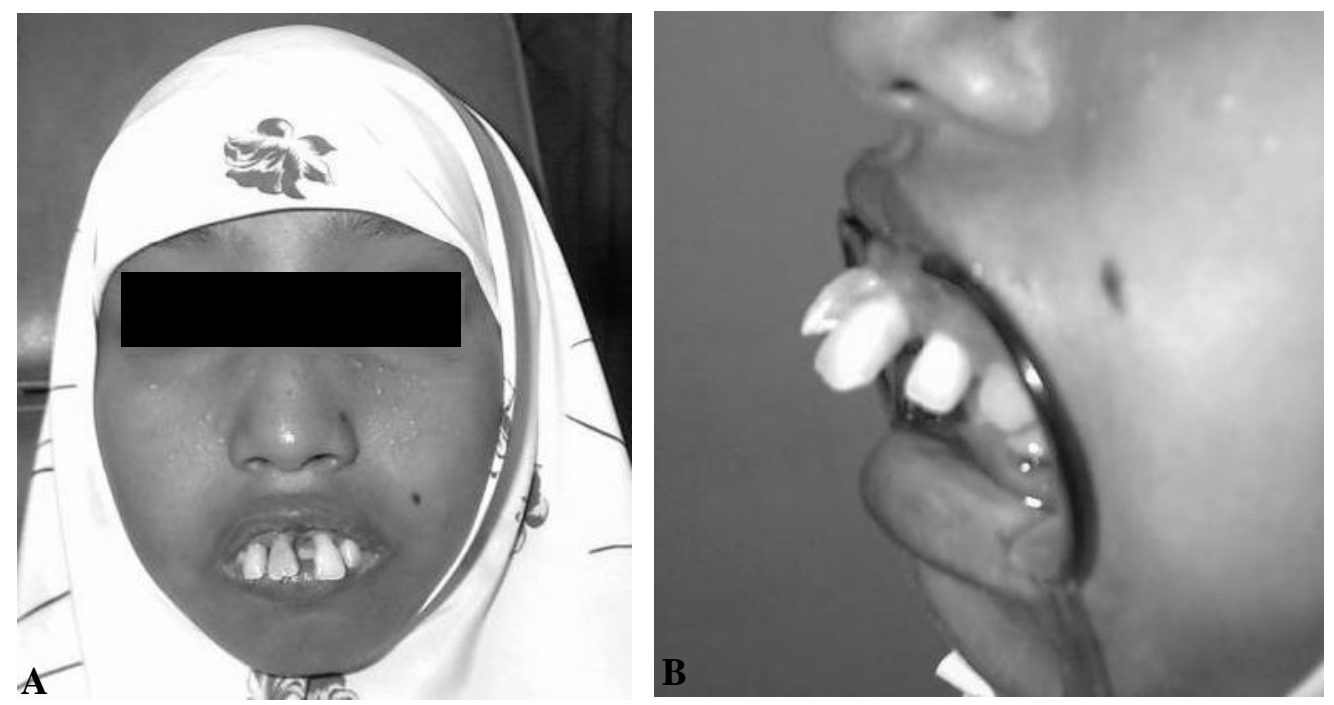

Gambar 1. Wajah penderita. A. Tampak depan. B. Tampak samping
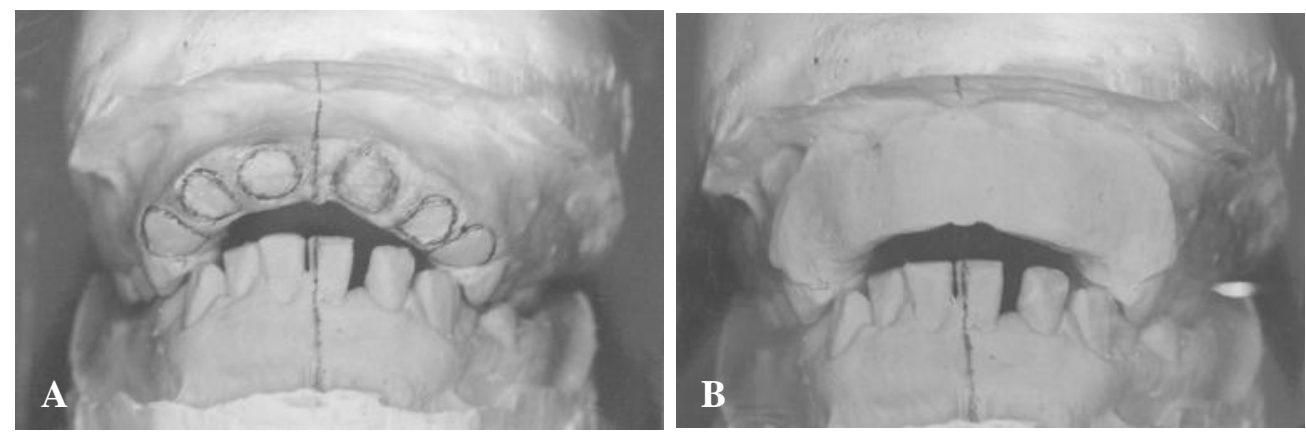

Gambar 2. Pengasahan pada model kerja. A. Pengasahan mahkota gigi. B. Pengasahan bagian labial.

Pada prosedur laboratoris dilakukan pengasahan pada model kerja yang meliputi serangkaian tahap, yaitu model kerja bagian servikal gigi yang akan dicabut ditandai dengan pensil (gambar 2A dan B). Selanjutnya dilakukan pemotongan dan pengasahan semua bagian mahkota gigi yang akan dicabut pada model kerja. Pengasahan pada model kerja sama dengan lingir alveolar yang akan dikeluarkan saat pembedahan.

Setelah pengasahan tersebut, dilakukan pembuatan surgical template, dan pembuatan klamer half Jackson pada gigi 14, 16, 24 dan 26, dan penyusunan gigi buatan 13, 12, 11, 21, 22 dan 23, serta dilanjutkan dengan proses akrilik.
Pada tata laksana bedah, diawali dengan disinfeksi dan anestesi daerah labial dan daerah palatal gigi 13 sampai 23. Selanjutnya dilakukan pencabutan gigi 13, 12, 11, 21, 22 dan 23 (gambar 3A) dan pemotongan tulang septum interdental dengan menggunakan tang knable dan dirapikan dengan bur fisur disertai irigasi larutan salin (gambar 3B). Selanjutnya tepi gingiva anterior digunting (gambar 3C). Kebutuhan pengambilan tulang dan jaringan dikontrol dengan menggunakan template yang telah disiapkan. Setelah sesuai dengan template, mukosa dijahit dengan cara interrupted suture, dan diakhiri dengan insersi gigitiruan dan daerah operasi dibersihkan (gambar 3D). 

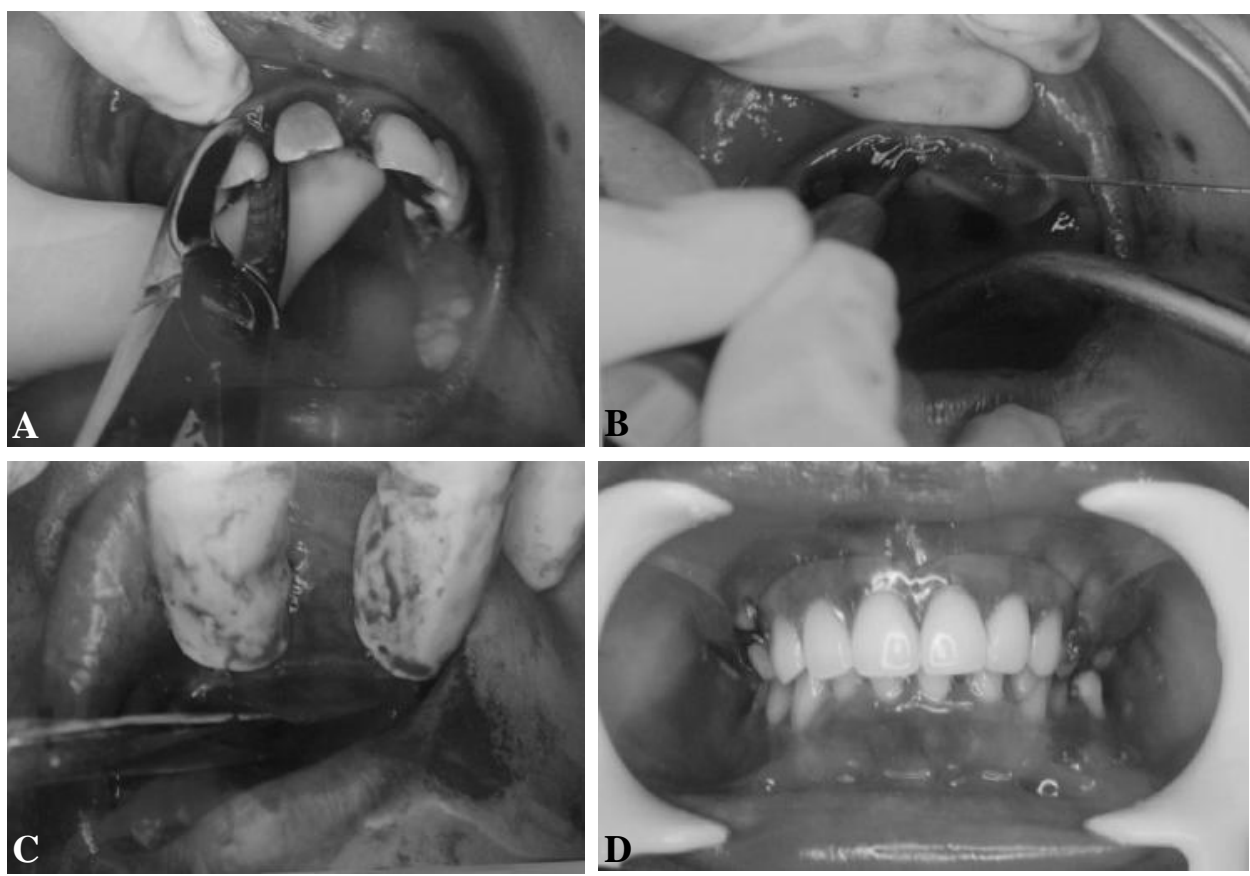

Gambar 3. Tata laksana pembedahan. A. Pencabutan gigi. B. Pemotongan septum interdental. C. merapikan tepi gingival. D. insersi gigitiruan.

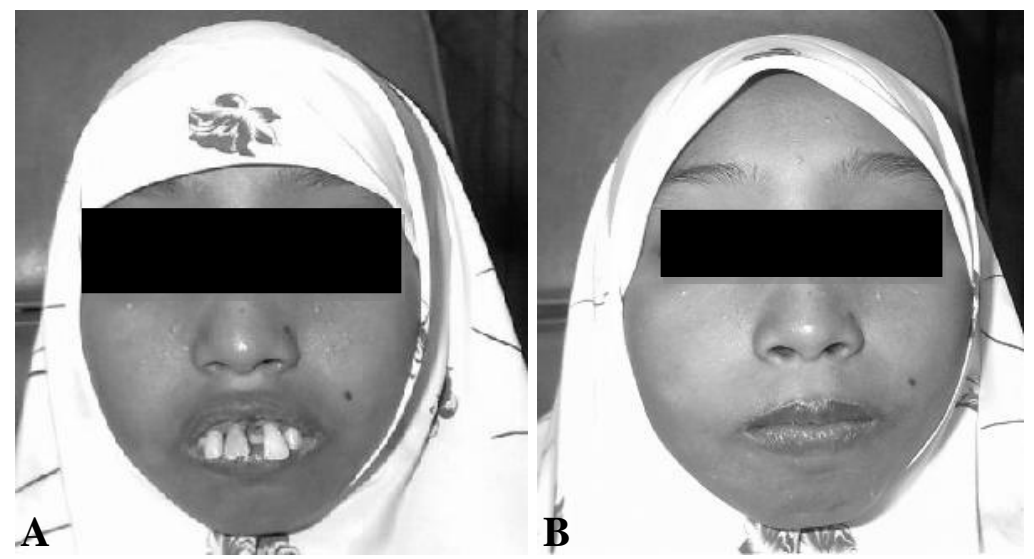

Gambar 4. Perbandingan wajah penderita sebelum dan setelah perawatan. A. Sebelum perawatan. B. Setelah perawatan.
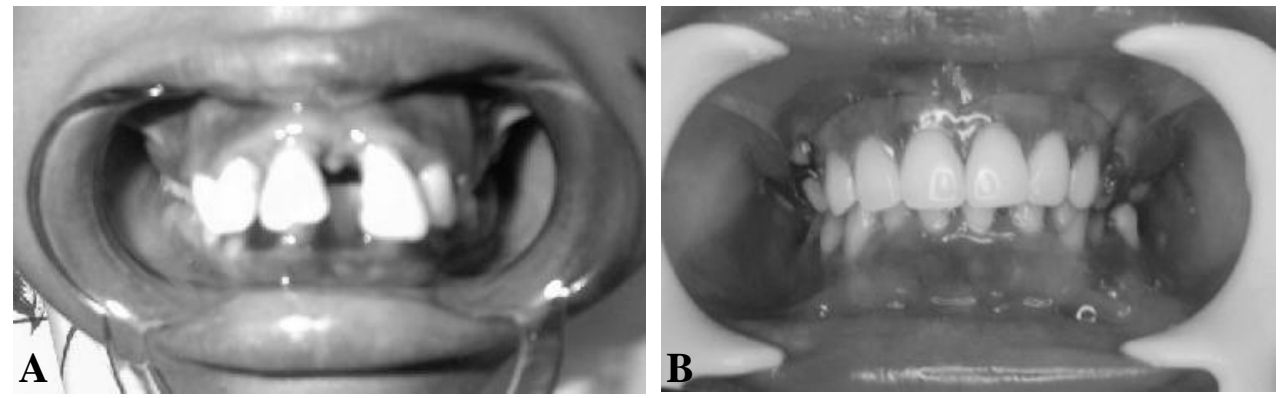

Gambar 5. Perbandingan keadaan intra oral penderita. A. Sebelum perawatan. B. Setelah perawatan. 
Retensi, stabilitas, oklusi, dan estetik gigitiruan dievaluasi secara seksama pada tahap insersi. Instruksi yang disampaikan kepada penderita adalah gigitiruan tidak boleh dilepas selama 24 jam pertama, makan makanan yang lunak, hindari makanan dan minuman yang panas, tidak boleh menggigit pada gigi depan, serta kompres dingin bila terjadi perdarahan.

Kontrol dilakukan setelah 24 jam pertama dengan melepaskan dan mencuci gigitiruan. Selanjutnya kontrol dilakukan 3 dan 7 hari kemudian. Kontrol berikutnya dilakukan setelah pemakaian 1 bulan, 2 bulan, dan 6 bulan.

\section{PEMBAHASAN}

Pada penderita dengan penyakit periodontal yang berlanjut, perawatan lokal periodontal yang berulang terkadang tidak bermanfaat dan kondisinya secara bertahap akan menjadi lebih buruk dan sulit untuk disembuhkan sehingga sampai pada satu keputusan bahwa tidak ada perawatan konservatif yang dapat menyembuhkan kondisi yang parah tersebut dan pada saat itulah perawatan prostodontik dipilih sebagai alternatif terbaik. Selain itu, setelah kehilangan tulang akibat penyakit periodontal, terlihat gigi migrasi ke labial dan diastema pada gigi anterior, sehingga mengakibatkan penampilan yang tidak menyenangkan bagi penderita. ${ }^{1}$ Pada keadaan demikian, gigi yang "kehilangan harapan" ini harus diekstraksi tanpa adanya keraguan dan dilanjutkan dengan perawatan prostodontik. Perawatan ini akan segera memberikan perbaikan fungsi, bentuk dan juga membangun kembali rasa percaya diri penderita (gambar 4 dan 5). ${ }^{10}$

Penanganan penderita yang didiagnosis sebagai dentoalveolar protrusion rahang atas yang disertai multiple diastema dengan maloklusi kelas II divisi 1 hubungan skeletal yang disebabkan oleh localized aggressive periodontitis adalah dengan pembuatan gigitiruan imidiat dengan ekstraksi imidiat pada gigi 13, 12, $11,21,22$, dan 23 yang disertai dengan alveolektomi interseptal pada regio $22,21,11$, dan 12 untuk perbaikan estetik gigi anterior yang akan memperbaiki penampilan wajah penderita. Sesuai dengan indikasi alveolektomi interseptal berkaitan dengan pemasangan gigitiruan imidiat, yaitu untuk mengurangi bagian depan maksila yang menonjol agar dapat menempatkan gigi anterior pada posisi yang lebih baik pada gigitiruan. $^{2}$

Metode alveolektomi interseptal yang dilakukan pada kasus ini mampu memberikan retrusi yang cukup pada tulang alveolar anterior untuk perbaikan posisi yang efektif pada insisivus yang protrusif. Tulang kortikal tidak mengalami trauma yang terlalu banyak sehingga derajat resorpsi setelah operasi dapat diturunkan. Terakhir, dengan cara ini pembukaan flap tidak diperlukan sehingga mengurangi rasa sakit dan rasa nyaman setelah operasi. ${ }^{9}$

Metode alveolektomi radikal tidak dilakukan dalam kasus ini karena walaupun dapat memenuhi derajat pengurangan tulang yang dibutuhkan tetapi bentuk tulang yang dihasilkan tidak stabil. Hal ini disebabkan karena soket yang kosong dari akar gigi yang dicabut hanya dimodifikasi pada bagian luar plat labial dengan proses pengasahan tulang. Selanjutnya resorpsi alveolar yang normal terjadi setelah ekstraksi. Proses ini dipengaruhi oleh jumlah bekuan darah dalam soket dan berikutnya adalah pengaturan tulang, ossifikasi dan remodeling tulang. Dengan demikian, ketika masa 6 bulan setelah operasi, derajat kehilangan tulang karena resorpsi tulang alveolar akan ditambah dengan kehilangan tulang oleh karena pengasahan plat tulang sebelah luar, sehingga tulang tidak cukup untuk memberikan dukungan dan retensi bagi gigitiruan. ${ }^{9}$ 
Penderita terlihat sangat puas setelah gigitiruannya diinsersikan. Tampak perubahan yang besar pada profil wajahnya. Bibir atas dan bawah sudah dapat menutup tanpa terganggu oleh gigi-gigi depannya. Walaupun demikian, bibir atas masih tampak tegang karena bibir atas yang pendek dan kaku akibat selama ini tertahan oleh gigi anterior rahang atas yang sangat protrusif.

Setelah pembedahan, pasien diinstruksikan minum obat teratur untuk mencegah terjadinya infeksi, perdarahan, serta rasa sakit yang mungkin timbul. Gigitiruan juga harus tetap dipakai selama 24 jam pertama. Kepada penderita dijelaskan bahwa jika gigitiruan dilepas lebih awal, dapat menyebabkan pembengkakan yang mengakibatkan gigitiruan tidak dapat dipasang kembali atau menimbulkan rasa sakit yang hebat. Penderita diinstruksikan untuk makan makanan yang lunak untuk menghindari trauma pada daerah operasi, menghindari makanan dan minuman yang panas serta mengandung $\mathrm{CO}_{2}$ seperti soft drink untuk mencegah terjadinya perdarahan. Selain itu, tidak boleh menggigit pada gigi depan. Kompres es dapat digunakan dingin bila terjadi perdarahan, meskipun hal ini jarang terjadi karena gigitiruan imidiat bertindak sebagai splint di atas daerah yang dibedah dan membantu mencegah terlepasnya gumpalan darah yang seringkali rusak oleh cairan dalam mulut. ${ }^{10}$

Kontrol tahap pertama setelah pemasangan gigitiruan dilakukan setelah 24 jam. Gigitiruan dilepas dan dicuci. Daerah operasi diirigasi dengan larutan salin normal. Adanya tekanan pada jaringan lunak terlihat dari warna mukosa yang terlihat lebih pucat bila dibandingkan dengan daerah sekitarnya yang bebas dari tekanan. Jika ada bagian gigitiruan yang menyebabkan tekanan berlebih, maka dapat langsung dikurangi. Pada kunjungan ini, penderita diajarkan cara memasang dan melepaskan gigitiruannya. Dianjurkan pula untuk berkumur-kumur dengan air garam hangat untuk mengeluarkan eksudat dari luka dan membuat vasodilatasi pembuluh darah yang akan meningkatkan suplai darah sehingga membantu mempercepat penyembuhan. ${ }^{8}$

Pada kontrol tahap kedua pada tiga dan tujuh hari setelah operasi, dilakukan koreksi lanjutan berupa perbaikan terhadap gangguan oklusi dan artikulasi. Diberikan instruksi untuk melakukan latihan memanjangkan bibir atas dengan menariknarik bibir atas. Selanjutnya kontrol dilakukan sebulan kemudian, lalu secara rutin sekali dalam enam bulan. Bila sudah terlihat adanya resorpsi yang ditandai dengan longgarnya basis, maka diperlukan relining. ${ }^{8}$

\section{SIMPULAN}

Pemilihan perawatan dengan menggunakan gigitiruan sebagian imidiat yang disertai dengan alveolektomi interseptal untuk memperbaiki estetik gigi anterior yang protrusif akibat kelainan periodontal yang parah merupakan alternatif terbaik. Sebelumnya, perlu dilakukan ekstraksi pada gigi anterior rahang atas yang dilanjutkan dengan pemotongan septum interseptal dan diikuti dengan pengasahan permukaan dalam bagian labial sehingga plat labial dapat dirapatkan dengan mudah tanpa perlu penekanan jari. Keuntungan utama dari perawatan ini adalah penderita terhindar dari rasa tidak nyaman dan khawatir bila terlihat tidak bergigi atau ompong, karena dapat segera memakai gigitiruan dengan posisi gigi artifisial yang lebih retrusi dari gigi alami sebelumnya. Dengan demikian tujuan penderita untuk mengubah dan memperbaiki kondisi dan posisi gigi anterior yang akhirnya akan memperbaiki estetik wajahnya dapat segera terwujud. 


\section{DAFTAR PUSTAKA}

1. Anderson JN, Storer R. Immediate and replacement dentures. $3^{\text {rd }}$ ed. Oxford: Blackwell Scientific Publications; 1981. p. 20, 31-3, 36, 40-1, 96, 146-64.

2. Basker RM, Davenport JC, Tomlin HR. Perawatan prostodontik bagi pasien tak bergigi (Prosthetic treatment of the edentulous patient). Alih bahasa: Soebekti TS, Arsil H. Edisi III. Jakarta: Penerbit Buku Kedokteran EGC; 1996. h. 37-44.

3. Iskandar R. Immediate denture. Majalah Kedokteran Gigi Indonesia. Edisi khusus. 1993. h. 1-5.

4. Sharry JJ. Complete denture prosthodontics. $3^{\text {rd }}$. ed. New York: McGraw-Hill Book Company; 1974. p. 295-309.

5. Gottlieb AS, Askinas SW. An atypical chairside immediate denture: A clinical report. J Prosthet Dent 2001; 86 (3): 214-3.
6. Heartwell CM, Rahn AO. Syllabus of complete dentures. $4^{\text {th }}$ Ed. Philadelphia: Lea \& Febiger; 1986. p. 441-57.

7. Gunadi HA, Burhan LK, Suryatenggara F, Margo A, Setiabudi I. Buku ajar ilmu geligi tiruan sebagian lepasan. Jilid II. Jakarta: Hipokrates; 1995. h. 367-78.

8. Soni A. Use of loss fitting copper bands over extremely mobile teeth while making impressions for immediate denture. J Prosthet Dent 1998; 81 (5): 638.

9. Grant AA, Johnson W. Removable denture prosthodontics. $2^{\text {nd }}$ Ed. Edinburgh: Churchill Livingstone; 1992. p. 247-91.

10. Zarb GA, Bolender CL, Hickey JC, Carlsson GE. Buku ajar prostodonti untuk pasien tak bergigi menurut Boucher (Boucher's prosthodontic treatment for edentulous patients). Edisi 10. Alih bahasa: Marjono D. Jakarta: Penerbit Buku Kedokteran EGC; 2002. h. 470, 476-7. 